10.2478/v10047-008-0009-3

\title{
SMALL-SCALE COGENERATION PLANT DATA PROCESSING AND
} ANALYSIS

\author{
I. Veidenbergs, D. Blumberga, C. Rochas, \\ F. Romagnoli, A. Blumberga, M. Rošā
}

Riga Technical University, Institute of Energy Systems and Environment, Kronvalda boulv. 1, Riga, LV-1010, LATVIA e-mail: dagnija.blumberga@rtu.lv

\begin{abstract}
In the article, the operational data on electricity and heat energy generation in a small-scale cogeneration plant are analysed. Different measurements done in the plant formed a basis for estimation and evaluation of the savings of primary energy in comparison with distributed energy production. The authors analyse the efficiency values for the heat and the electricity production in the cogeneration regime and the savings of primary energy when the cogeneration plant works with partial load.

Key words: electricity production, heat energy production, cogeneration, efficiency, measurements, primary energy savings.
\end{abstract}

\section{INTRODUCTION}

As any other technical system, cogeneration plants are based on physical processes that characterise fundaments of the processes - simultaneous production of several types of energy. The regularities derived during the study and the quantitative results can form a basis for the development of new system methods. However, in the real equipment the process is not free; it is limited by technical, economical, environmental, legislative, and other conditions like requirements concerning the guarantees of definite efficiency, the minimum operational time in a year, and the economy of primary resources in comparison with distributed energy production. Therefore, investigation of real equipment and its analysis are associated with studying the processes concerned under given conditions and restrictions. The task of the research is to determine possibilities to improve the equipment and its operation under these conditions.

The objective of the analysis is to examine the parameters of a small-scale cogeneration plant and energy efficiency measures, and, based on the information obtained, to develop the methodology for analysing a real plant's operation. For this analysis, a small-scale energy source has been chosen, with cogeneration equipment integrated into the technological scheme. At the cogeneration plant a small-scale gas engine is installed.

The cogeneration equipment is positioned in a district heating (DH) system and operates in parallel with a water-heating boiler. The heat energy produced is used for heating a residential sector and its supplying with hot water. The cogeneration plant is connected to the electricity grid and has a possibility to supply electricity to consumers or deliver it to the grid. Connection to the grid ensures the 
plant's operation with the maximum electricity load, because the amount of energy that exceeds the demand of the consumers can be delivered to the grid. The electrical load is determined based on the heat energy consumption and its variations under different operational regimes [1].

The cogeneration plant is selected based on the DH system heat load that is defined by the area to be heated, the hot water load, and the heat supply losses.

The heat load duration graph of the consumer is usually shown as relative or normalized load variation during a year. The relative load is calculated by the equation:

$$
r=\frac{N_{Q}}{N_{Q_{\max }}},
$$

where $r \quad-$ the relative load;

$N_{Q} \quad$ - the capacity of the plant, MW;

$N_{Q_{\max }}$ - its maximum capacity, MW (in this case $1.05 \mathrm{MW}$ ).

For selection of the heat load for a cogeneration plant various criteria exist. If one of the requirements is the equipment operational time of $7000 \mathrm{~h}$ per year, then the relative load of the equipment installed can be 0.12 (or $130 \mathrm{~kW}$ ). This means that the equipment is installed based on the hot water heat load that is low but available throughout the year.

In this case the current capacity of the cogeneration plant is $265 \mathrm{~kW}$ or 0.25 of the maximum available load. With this load the equipment can operate approx. $4400 \mathrm{~h}$ a year.

For the quantitative analysis of the cogeneration plant's operation, measurements of the following parameters during a year have been performed:

- the heat energy produced in the cogeneration ( $Q, \mathrm{MWh} /$ day);

- the electricity produced in the cogeneration $(W, \mathrm{MWh} /$ day $)$;

- the number of operation hours of the cogeneration plant (h/day);

- the natural gas consumption in the cogeneration plant $\left(B, \mathrm{~m}^{3} /\right.$ day).

\section{MEASUREMENT DATA PROCESSING AND RESULTS}

As a result of the data statistical processing, the heat and electrical load correlation can be described by the regression equation:

$$
N_{Q}=0.035+2.294 \cdot N_{e l}-6.134 \cdot N_{e l}^{2}, \mathrm{MW},
$$

where $N_{Q}$ is the heat capacity of the cogeneration plant, MW;

$N_{e l}$ is the electrical capacity of the cogeneration plant, MW.

The derived regression equation is a mathematical model of the analysed process that has to be evaluated from several aspects.

Correlation of heat and electrical loads can be evaluated with the help of a correlation coefficient. Analysis shows that the defined $R^{2}$ value is 0.778 (the correlation coefficient is $R=0.88$ ). The value of correlation coefficient indicates 
close interconnection between the heat and the electrical load. The created model (2) explains $77.8 \%$ of the analysed electrical load deviations. The remaining $22.2 \%$ can be associated with independent variables that were not defined in the analysis or included in the equation, or arise due to the interconnection effect.

Another evaluation of the model is related to verification of its adequacy. The evaluation has been performed with the dispersion analysis using the Fisher criterion $(F)$.

The estimation of Fisher's criterion was computer-aided, with the value $F=85.67$ obtained (the tabular value of Fisher's criterion is $F_{t a b}=1.76$ ). As is seen, the relationship $F>F_{\text {tab }}$ is valid, which means that Eq. (2) is adequate and can be applied for describing the analysed data in the range of their variations.

In the case of a multifactor analysis, the autocorrelation verification has been performed. It has been affirmed that there is no significant autocorrelation of residues, and the estimation of the values by the least square method has shown no distortions.

The above described acquisition of the empiric correlation data and the verification method are used for the further data analysis and evaluation of the results; and, although no detailed explanations are provided for each case, the useful information on the correlation and its use is given.

The variation of the heat load versus the electrical load in a cogeneration plant in the partial load regime is shown in Fig. 1.

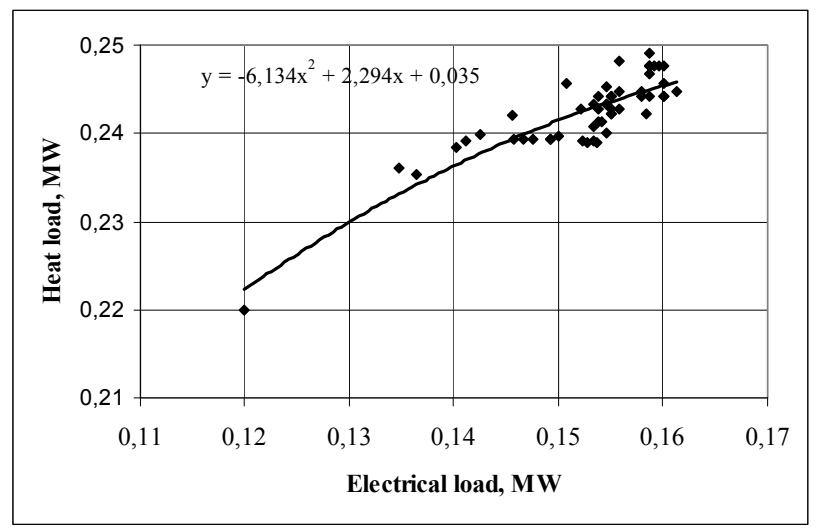

Fig. 1. Variation of the heat load vs. electrical load.

Equation (2) and Fig. 1 demonstrate that at reducing the electrical load the heat load decrease is non-linear. The minimum heat load of $3.5 \mathrm{~kW}$ is in the case of the absence of electrical load. This is the gas engine stand-by load, which is around $1.3 \%$ of the nominal heat load.

An important characteristic of a cogeneration system is the ratio of electrical and heat loads $(\alpha)$. This ratio shows what electrical load per heat load unit can be provided by a particular technology, or how many $\mathrm{kWh}$ of electricity can be produced per $1 \mathrm{kWh}$ of the heat energy supplied to the consumer. The $\alpha$ ratio characterises the ability of a thermal engine to generate electricity using the cogeneration equipment, being a significant factor for the calculation of the electricity produced in cogeneration regime: 


$$
\alpha=\frac{N_{e l}}{N_{Q}}=\frac{W}{Q}=\frac{r_{e l}}{r_{Q}},
$$

where $W$ - the electricity produced in the cogeneration plant, $\mathrm{MWh} /$ day;

$Q$ - the heat energy produced in the cogeneration plant, $\mathrm{MWh} /$ day;

$r_{e l}$ - the efficiency of electricity production in the cogeneration plant;

$r_{Q}$ - the efficiency of heat energy production in the cogeneration plant.

The $\alpha$ ratio is taken from the passport of the equipment, with its value given for the nominal regime. However, since such equipment operates also under partial load, additional information is needed about variations in the $\alpha$ values in various regimes. In this work, such variations were estimated based on the operational data of a cogeneration plant and on the processed results. According to Eqs. (2) and (3), the $\alpha$ ratio can be defined as:

$$
\alpha=\frac{N_{e l}}{-6.13 \cdot N_{e l}^{2}+2.294 \cdot N_{e l}+0.035} .
$$

The $\alpha$ variations estimated using Eq. (4) for different operational loads are graphically plotted in Fig. 2. The set of processed data is $m=155$.

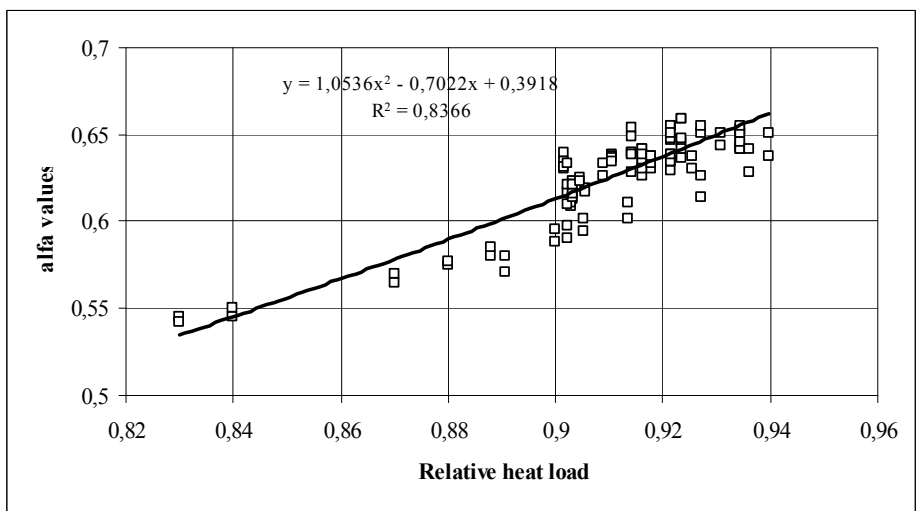

Fig.2. Variations of $\alpha$ value vs. the relative heat loads

The data correlation analysis shows that the function $\alpha=f\left(q_{Q}\right)$ can be written in the form:

$$
\alpha=1.054 \cdot q_{Q}^{2}-0.702 \cdot q_{Q}+0.0392 .
$$

This equation describes well the variations of $\alpha$ (the squared value of the correlation coefficient being $R^{2}=0.84$ ).

Another group of parameters that illustrates the cogeneration plant's operation is its efficiency. It is necessary here to estimate the total efficiency of the plant $\eta_{t o t}$, which characterises the efficiency of the use of primary resources for production of both kinds of energy - heat and electrical, as well as $r_{e l}$ and $r_{Q}$ for separate generation of energy. 
Using the operational data of the cogeneration plant (the data set being $m=283$ ) and performing their statistical analysis, the empirical equations for the efficiency calculation for different loads of the plant can be obtained. For this purpose, one-factor and multiple-factor regression analyses have been used.

For calculating the total efficiency of the cogeneration plant the following empiric equation was applied:

$$
\eta_{\text {tot }}=0.016 \cdot q_{Q}+0.845 .
$$

In turn, to determine the efficiency for separate energy productions the following equations could be used:

$$
r_{Q}=-0.065 \cdot q_{Q}+0.581
$$

for the efficiency of heat energy generation, and

$$
r_{e l}=-0.525 \cdot q_{Q}^{2}+1.071 \cdot q_{Q}-0.201
$$

for the efficiency of the electricity generation.

Variations in the efficiency are considered in dependence on the heat load changes of the equipment. Equations (6) and (7) have been obtained with onefactor regression analysis and Eq. (8) - with the multiple-factor regression analysis. Equation (8) was estimated for statistical significance of the coefficients, and the assessment of the equation has been performed. For all coefficients of the equation the function $|t|>t_{t a b}$ is valid, therefore they are substantial and must be kept in the mentioned equation.

The Fisher criterion derived using the dispersion analysis is $F=179.6$, with the relationship $F>F_{\text {tab }}$ being valid. This means that Eq. (8) is adequate and can be applied for describing the data analysed in the range of their variations. The efficiency variations of the cogeneration plant for different relative heat loads are shown in Fig. 3.

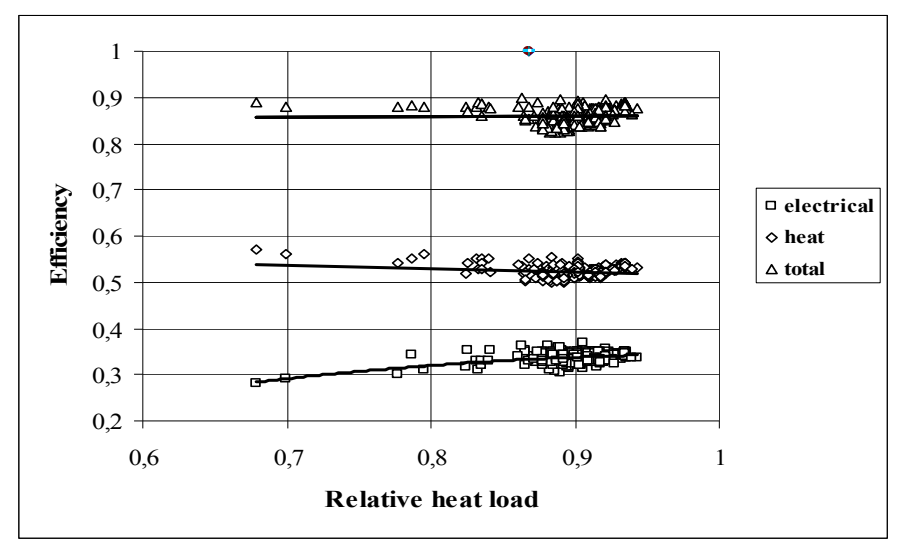

Fig. 3. Variations in efficiency of the cogeneration plant vs. relative heat load.

Typically, in the cogeneration plants with gas engines when the relative load of a plant is reduced to 0.7 of the nominal, the efficiency practically does not change. 
The total efficiency of a cogeneration plant is described by the following equation involving the efficiencies of separate energy production:

$$
\eta_{t o t}=r_{e l}+r_{Q} \text {. }
$$

The total efficiency can remain invariable if the efficiencies of separate energy production change oppositely. At the relative load decreasing, the efficiency of heat generation $r_{Q}$ increases linearly, and the change is small. By comparison, more significant variations can be observed for the efficiency of electricity generation $r_{e l}$. The character of the variations is non-linear and is more evident in the cases of smaller loads, with the efficiency remaining practically invariable in the relative load range of $0.75-1.0$.

The empiric equations that have been derived in the statistical processing of the measurement data can be used when studying the operation of a plant and for the estimation of its specific indicators.

\section{EVALUATION OF SAVINGS OF PRIMARY RESOURCES AT THE PLANT}

The use of cogeneration is justifiable if the consumption of primary energy is smaller in comparison with separate electricity and heat energy production. Savings of primary energy in the case of cogeneration mean that the saved fuel can be used to produce the same amounts of electricity and heat in comparison with the separate production in the reference electrical power plant and boiler house. The efficiency values at separate electricity and heat production by the reference plants in Latvia that can be used for calculations are approved by the Cabinet of Ministers [4].

The most common approach is to estimate the relative primary energy savings calculated as the absolute values against the fuel energy for separate energy production $\left(Q_{\text {fuel,sep }}\right)$. For this purpose the following equation is applied:

$$
\delta Q_{P E}=\left(1-\frac{Q_{\text {fuel }}}{\frac{W}{\eta_{\text {el,sep }}}+\frac{Q}{\eta_{Q, \text { sep }}}}\right) \cdot 100=\left(1-\frac{1}{\frac{r_{\text {el }}}{\eta_{\text {el,sep }}}+\frac{r_{Q}}{\eta_{Q, \text { sep }}}}\right) \cdot 100, \% .
$$

Savings of relative primary energy can be calculated also in the case when their absolute values are taken against the fuel energy used for cogeneration $\left(Q_{\text {fuel }}\right)$. In this case the recalculation should be performed, and the values obtained using Eq. (10) are to be multiplied by $\frac{Q_{f u e l}}{Q_{f u e l, s e p}}$.

The relationship between the real fuel savings and the primary energy savings is described by the equation:

$$
\Delta B=\frac{\Delta Q_{P E}}{Q_{z}^{d}} .
$$

If the primary energy savings calculated by Eq. (10) are at least $10 \%$, then the cogeneration plant belongs to a higher efficiency cogeneration group, to which the terms of the state mandatory electricity purchase regulation are applied. 
Using Eqs. (7) and (8) describing the $r_{e l}$ and $r_{Q}$ efficiencies, for the case of natural gas with $\eta_{e l, s e p}=0.45$ and $\eta_{Q, s e p}=0.90$, expression (10) can be modified as

$$
\begin{aligned}
\delta Q_{P E} & =\left(1-\frac{1}{\frac{-0.525 q_{Q}^{2}+1.071 q_{Q}+0.201}{0.45}+\frac{0.065 q_{Q}+0.581}{0.90}}\right) \cdot 100= \\
& =\left(1-\frac{1}{-1.167 q_{Q}^{2}+2.31 q_{Q}+0.199}\right) \cdot 100, \% .
\end{aligned}
$$

Equation (12) can be used for estimation of the proportional primary energy savings when the plant operates in partial load regimes. Variations of the savings are shown in Fig. 4. This figure presents the values of savings in the operational regimes $-q_{Q}=0.5 ; 0.6 ; 0.75 ; 1.0$, which were chosen to illustrate the saving variations in the range of practically applicable loads.

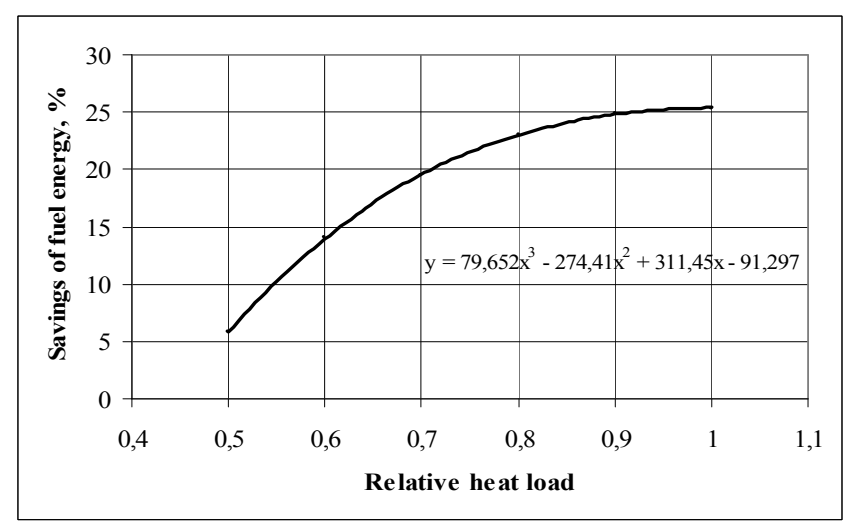

Fig. 4. Primary energy savings during the plant operation in partial load regimes.

The figure shows that if a cogeneration plant is operating in full load the primary energy savings are higher, reaching $25 \%$. If the load is being reduced, the savings are decreasing non-linearly, and the high-efficiency cogeneration plant reaches the limiting value of savings of $10 \%$ when the relative load is 0.55 of the maximum. If the relative load is about 0.45 , there are no primary energy savings and the cogeneration becomes equivalent to the separate energy production. If the relative load is lower than 0.45 , the consumption of primary energy is greater than that in the case of separate energy production, which would mean financial losses. The range of the relative load was chosen not taking into account the uncertainty of savings and is therefore approximate. In general, the figure above allows making quantitative analysis of the plant operation for different load regimes.

Along with the cogeneration equipment, water-heating boilers were installed at the boiler house, which allow, operating separately or together with the cogeneration equipment, coverage of the heat load for the consumers. The electrical 
load for the consumers can be covered from the electrical grid. This means that the cogeneration equipment can operate continuously under full or partial load or, in the case when the load is reduced, it can be switched off. In this case the cogeneration equipment will operate in the on-off mode, therefore the daily energy production will be smaller. It should be noted that during the operation of the plant the primary resource savings in the case under consideration are as described above, although the absolute values of savings in the on-off mode are smaller.

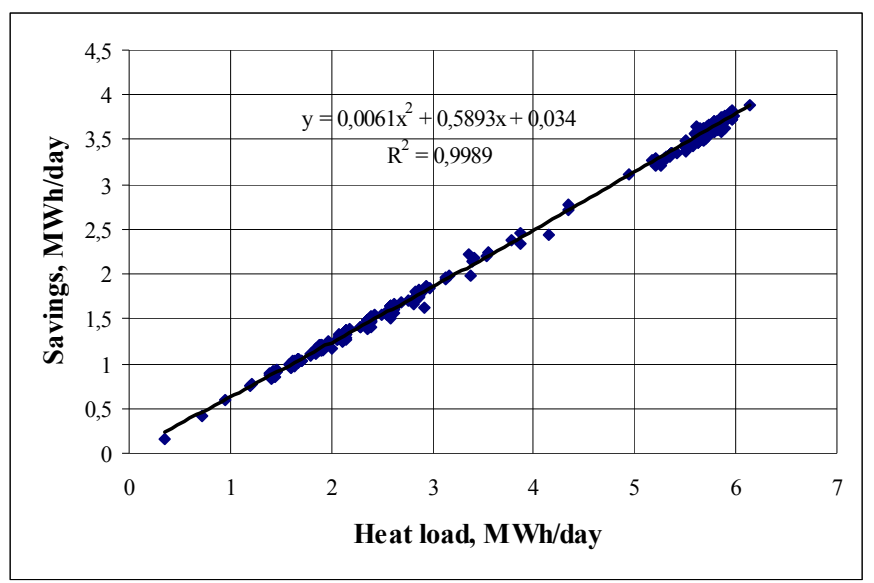

Fig .5. Daily primary energy savings $v s$. heat energy load in a cogeneration cycle.

In Fig. 5, the daily primary energy savings versus the heat energy generated in a cogeneration cycle are summarised. The graph allows estimation of the primary energy and, therefore, of the fuel savings in the case of different heat loads of the plant. As can be seen, the function is close to linear. Its minor non-linearity is caused by the efficiency decrease in the case of small production.

\section{CONCLUSIONS}

1. The empiric equations that have been derived in the statistical processing of the measurement data can be used when studying the operation of a plant and for the estimation of its specific indicators. The empiric ratio of electrical and heat load and relative heat load $\alpha=f\left(q_{Q}\right)$ has been estimated, and the analysis shows good correlation $\left(R^{2}=0.84\right)$. Similar empiric equations have been applied for calculation of the efficiency versus the relative heat load.

2. The total efficiency can remain invariable if the efficiencies of separate energy production change oppositely. At the relative load decreasing, the efficiency of heat generation $r_{Q}$ increases linearly, and the change is small. More significant variations can be observed for the efficiency of electricity generation $r_{e l}$. The character of the variations is non-linear and is more evident in the cases of smaller loads, with the efficiency remaining practically invariable in the relative load range of $0.75-1.0$.

3. Based on the measurements made at the cogeneration plant, the primary energy savings were calculated and evaluated in comparison with distributed energy production. 
4. An equation for estimation of the proportional primary energy savings when the plant operates under partial load has been obtained $\left(q_{Q}=0.5 ; 0.6 ; 0.75\right.$; 1.0 ). The operation variables were chosen to illustrate the saving variations in the range of practically applicable loads.

5. If cogeneration plant is operating in full load the primary energy savings are higher, reaching $25 \%$. If the load is reduced, the savings decrease non-linearly, and the high-efficiency cogeneration plant reaches the limiting value of savings of $10 \%$ when the relative load is 0.55 of the maximum. If the relative load is about 0.45 , there are no primary energy savings and the cogeneration becomes equivalent to the separate energy production. If the relative load is lower than 0.45 , the consumption of primary energy is greater than that in the case of separate energy production, which would mean financial losses.

6. The statistical analysis methodology presented in the article can be used for analysing the operation of other cogeneration plants and estimation of their indicators.

\title{
REFERENCES
}

1. Mineikis, G., Veidenbergs, I. \& Dzene, I. (2006). Experience of operation of smallscale cogeneration plants in Latvia. Proceedings of International Scientific Conference "Power and Electrical Engineering", series 4, issue 17, Riga: RTU, p. 240-246 (in Latvian).

2. Revina, I. (2002). Econometry. Riga: University of Latvia (in Latvian).

3. Veidenbergs, I. \& Blumberga, A. (Oct. 11-13, 2001). Energy consumption regression model for buildings. Proceedings of International Scientific Conference "Power and Electrical Engineering”, Riga, p.125-130 (in Latvian).

4. Regulation of Cabinet of Ministers No. 921, 11.11.2006.

\section{MAZAS JAUDAS KOĢENERĀCIJAS STACIJAS DARBINĀŠANAS DATU APSTRĀDE UN ANALİZE}

\author{
I. Veidenbergs, D. Blumberga, C. Rochas, \\ F. Romagnoli, A. Blumberga, M. Rošā
}

Kopsavilkums

Rakstā analizēti elektroenerǵijas un siltumenerǵijas ražošanas inženiertehniskie darbības rādītāji mazas jaudas koǵenerācijas stacijā. Veikti mērījumi koǵenerācijas stacijāa uz kuriem balstoties veikta primārās enerǵijas ietaupījumu noteikšana un vērtēšana, salīdzinot ar dalītas enerğijas izstrādi. Analizētas elektroenerǵijas un siltumenergíjas ražošanas lietderības koeficientu vērtības koǵenerācijas režīmā. Veikta primāro energoresursu ietaupījumu analīze, koǵenerācijas stacijai darbojoties ar dalsēju noslodzi.

09.06.2008. 